\title{
PERFORMA DOMBA LOKAL BETINA DEWASA \\ PADA BERBAGAI VARIASI LAMANYA PENGGEMBALAAN DI DAERAH IRIGASI RENTANG KABUPATEN MAJALENGKA
}

\section{LOCAL EWES PERFORMANCE AT VARIOUS VARIATION OF LENGTH GRAZING IN RENTANG IRIGATION AREA OF MAJALENGKA REGENCY}

\author{
Rachmat Somanjaya ${ }^{1}$, Denie Heriyadi ${ }^{2}$, dan Iman Hernaman ${ }^{2}$ \\ 1. Alumni Program Pascasarjana Fakultas Peternakan Universitas Padjadjaran \\ 2. Fakultas Peternakan Universitas Padjadjaran \\ e-mail : rachmatsomanjaya@yahoo.com
}

\begin{abstract}
Abstrak
Penelitian ini bertujuan untuk mengukur lamanya waktu penggembalaan optimum terhadap performa domba lokal betina dewasa yang digembalakan di Daerah Irigasi Rentang Kecamatan Jatitujuh Kabupaten Majalengka. Sampel domba lokal betina dewasa dalam penelitian ini adalah sebanyak 62 ekor yang tersebar pada variasi penggembalaan <4 jam (19 ekor), 4-6 jam (21 ekor), dan >6 jam (22 ekor). Metode penelitian yang digunakan adalah survey dan observasi. Data yang diperoleh dianalisis secara deskriptif, untuk mengetahui perbedaan rata-rata performa domba diuji dengan One Way ANOVA serta dilanjutkan dengan uji jarak berganda Duncan. Hasil penelitian menunjukkan bahwa penggembalaan $>6$ jam merupakan lama penggembalaan yang optimum, dibuktikan dengan performa induk secara keseluruhan lebih baik dari lama penggembalaan $<4$ jam dan $4-6$ jam.
\end{abstract}

Kata Kunci : domba lokal, lama penggembalaan, performa produksi, dan potensi hijauan

\begin{abstract}
This research was held to measure the optimum grazing duration on local ewes performance in Rentang Irrigation Area of Kecamatan Jatitujuh Majalengka Regency. Local ewes sample in this reseach were 62 and they were spread on grazing variation $<4$ hours ( $n=19)$, 4-6 hours ( $n=21)$, and $>6$ hours $(n=22)$. The research method used was survey and observation. Data were analyzed descriptively, to determine differences in the average performance of sheep tested with one-way ANOVA, followed by Duncan's multiple range test. The results showed that $>6$ hours was the optimum grazing time, proved by the ewes' overall performance overall which was better than $<4$ and $4-6$ hours of grazing.
\end{abstract}

Key words $\quad$ : Local sheep, grazing length, performance of production, and potential forage

\section{PENDAHULUAN}

Domba yang dipelihara oleh peternak di pedesaan mayoritas adalah domba lokal. Keunggulan domba lokal adalah bersifat prolifik, artinya mempunyai rataan jumlah anak lahir (lamb crop) yang lebih dari satu yaitu $\geq 1,75$ ekor (Inounu, $d k k$., 1999). Peternak domba di pedesaan rata-rata memelihara ternak dengan cara digembalakan. Pemeliharaan domba dengan cara digembalakan sangat mempengaruhi performa produksi, karena sangat bergantung atas ketersediaan hijauan pakan di padang penggembalaan baik kuantitas atau pun kualitasnya. Kuantitas dan kualitas hijauan yang dikonsumsi menjadi penyebab baik tidaknya performa induk domba yang digembalakan.

Penggembalaan domba di Kabupaten Majalengka dilakukan dengan durasi waktu yang berbeda-beda sesuai dengan kebiasaan peternak. Hasil analisis pendahuluan diperoleh bahwa rata-rata durasi waktu penggembalaan antara empat sampai dengan tujuh jam. Kondisi tersebut tentunya berpengaruh terhadap performa produksi domba karena erat kaitannya dengan pakan atau hijauan yang dikonsumsi.

Kabupaten Majalengka memiliki potensi lahan hijauan yang belum digunakan secara optimum. Potensi tersebut adalah tanggul-tanggul daerah Irigasi Rentang yang memiliki luas administrasi $390,48 \mathrm{~km}^{2}$, memanjang di tiga wilayah yaitu Kabupaten Majalengka, Cirebon, dan Indramayu (Departemen Pekerjaan Umum, 2008). Potensi daya tampung areal lahan penggembalaan ini cukup tinggi untuk pengembangan usaha domba.

Peternak sudah terbiasa menggembalakan dombanya di sekitar tanggul-tanggul daerah irigasi tersebut. Lamanya penggembalaan di daerah irigasi akan berpengaruh terhadap performa induk domba. Performa domba lokal betina dewasa dapat diketahui dengan mengumpulkan data antara lain rata-rata bobot badan induk, jumlah induk melahirkan dan jumlah induk bunting kembali, tipe kelahiran, lamb crop, rasio jenis kelamin anak, bobot lahir, bobot sapih anak, dan jumlah mortalitas anak.

\section{METODE}

Penelitian dititikberatkan kepada pengukuran lamanya penggembalaan yang biasa dilakukan oleh peternak domba lokal di sekitar daerah Irigasi Rentang, dikaji berdasarkan performa produksinya. Ternak percobaan dalam penelitian ini adalah domba lokal 
betina dewasa sebanyak 62 ekor. 62 ekor domba lokal betina dewasa tersebut terbagi kedalam tiga waktu penggembalaan. Jumlah domba lokal betina dewasa yang digembalakan <4 jam sebanyak 19 ekor, 4-6 jam sebanyak 21 ekor, dan $>6$ jam sebanyak 22 ekor.

Penelitian dilakukan dengan cara observasi langsung pada ternak dan survey kepada peternak domba lokal yang menggembalakan dombanya di daerah Irigasi Rentang. Kriteria lain dalam penelitian ini adalah kebiasaan peternak yang tidak memberikan pakan tambahan setelah atau pun sebelum digembalakan saat dikandangkan. Peternak yang dijadikan sampel ditentukan dengan menggunakan metode purposive sampling atau pemilihan sampel secara sengaja.

\section{Prosedur}

Kegiatan utama penelitian adalah pengambilan data produksi induk domba lokal yang digembalakan berdasarkan perbedaan lamanya penggembalaan. Data produksi atau performa domba lokal betina dewasa yang dikumpulkan adalah rata-rata bobot badan Domba Lokal betina dewasa, persentase induk melahirkan dan bunting kembali, tipe kelahiran, jumlah anak sekelahiran (lamb crop), rasio jnis kelamin anak, bobot lahir, bobot sapih anak umur 4 bulan, dan tingkat kematian/mortalitas anak.

Prosedur pengukurannya adalah sebagai berikut :

1) Bobot badan domba betina dewasa, diukur dengan cara ditimbang menggunakan timbangan pegas (salter) dengan kapasitas $50 \mathrm{Kg}$.

2) Persentase induk melahirkan dan bunting kembali, dihitung berdasarkan jumlah induk yang melahirkan atau sedang bunting bunting paskamelahirkan dibagi jumlah total induk dikali $100 \%$.

3) Tipe kelahiran, adalah pengkategorian induk berdasarkan tipe kelahiran tunggal atau kembar. Seekor induk mampu melahirkan satu, dua, tiga anak bahkan lebih dalam satu kelahiran.

4) Jumlah anak sekelahiran (lamb crop), adalah jumlah anak total yang dilahirkan oleh satu induk domba dalam satu kelahiran.

5) Rasio jenis kelamin anak, didapat dari perbandingan antara jumlah anak domba jantan dengan jumlah anak domba betina.

6) Bobot lahir, dihitung berdasarkan berat anak domba yang ditimbang setelah lahir sampai dengan maksimum 24 jam.

7) Bobot sapih, adalah bobot anak domba saat dipisahkan dari induknya. Campbell et al. (2003) menyatakan anak domba dapat disapih dari induknya 2-5 bulan.

8) Tingkat kematian anak, atau persentase kematian anak dilihat dari banyaknya anak yang mati dari jumlah anak yang hidup setelah 1 bulan dilahirkan.

\section{Analisis Data}

Data performa produksi yang diperoleh dianalisis secara deskriptif (Gasperz, 1995), untuk memperoleh nilai rataan, nilai minimum, nilai maksimum, koefisien variasi, dan simpangan baku. Selanjutnya untuk mengetahui adanya respon dari lamanya penggembalaan terhadap performa domba lokal betina dewasa yang digembalakan di daerah Irigasi Rentang Kabupaten Majalengka, dilakukan dengan analisis sidik ragam satu arah atau One-Way ANOVA. Kemudian untuk melihat perbedaan antar perlakuan, dilakukan dengan uji jarak berganda Duncan (Steel dan Torrie, 1993). Semua pengujian dilakukan dengan menggunakan SPSS 16 software for Windows.

\section{HASIL DAN PEMBAHASAN}

\section{Rata-rata Bobot Badan Induk}

Rata-rata bobot badan Domba Lokal (Domba Wonosobo) betina dewasa yang dijadikan bibit adalah $60,64 \pm 9,07 \mathrm{~kg}$ (Syuhada, dkk. 2014), sedangkan bobot badan bibit Domba Garut sebagai persyaratan kuantitatif minimum adalah $37 \mathrm{Kg}$ (Badan Standardisasi Nasional, 2009). Hasil penelitian menunjukkan bahwa bobot badan Domba Lokal betina dewasa yang digembalakan di sekitar Daerah Irigasi Rentang Kabupaten Majalengka berada di bawah standar. Ratarata bobot badan domba tersebut antara $18,7-27,5 \mathrm{Kg}$, lebih rinci disajikan dalam Tabel 1.

Hasil analisis statistik menunjukkan bahwa rata-rata bobot badan tertinggi adalah Domba Lokal betina dewasa yang digembalakan antara empat sampai enam jam. Bobot badan Domba Lokal betina dewasa yang digembalakan lebih dari empat jam berbeda nyata $(P<0,05)$ lebih tinggi dibandingkan Domba Lokal betina dewasa yang digembalakan $<4$ jam. Hal tersebut dapat disebabkan oleh feed intake domba yang digembalakan $<4$ jam lebih sedikit dibandingkan durasi penggembalaan lainnya. Selain feed intake, kualitas pakan yang dikonsumsi juga berpengaruh terhadap pertambahan bobot badan domba.

\section{Persentase Induk Melahirkan dan Induk Bunting Kembali}

Jumlah induk melahirkan dihitung berdasarkan kondisi induk yang sedang memiliki anak dibawah umur lepas sapih. Sedangkan pemeriksaan kebuntingan dilakukan dengan palpasi abdomen sehingga induk domba yang dapat dideteksi kebuntingannya adalah induk dengan umur kebuntingan lebih dari tiga bulan. Jumlah induk melahirkan dan induk bunting kembali pascamelahirkan yang terdeteksi pada saat penelitian dapat dilihat dalam Tabel 2.

Tabel 1. Rata-Rata Bobot Badan Domba Lokal Betina Dewasa yang Digembalakan di Daerah Irigasi Rentang 


\begin{tabular}{ccc}
\hline $\begin{array}{c}\text { Lama Penggembalaan } \\
(\text { jam })\end{array}$ & $\begin{array}{c}\text { Jumlah Induk (N) } \\
\text { (ekor) }\end{array}$ & $\begin{array}{c}\text { Bobot Badan } \\
\text { (kg } \pm \text { SD) }\end{array}$ \\
\hline$<4$ & 19 & $18,71 \pm 1,28^{\mathrm{a}}$ \\
$4-6$ & 21 & $27,50 \pm 2,04^{\mathrm{b}}$ \\
$>6$ & 22 & $26,68 \pm 2,16^{\mathrm{b}}$ \\
\hline
\end{tabular}

Keterangan: Superskrip huruf yang berbeda pada kolom yang sama menunjukkan perbedaan yang nyata $(P<0,05)$

Tabel 2. Persentase Induk Melahirkan dan Induk Bunting Kembali pada Domba Lokal Betina yang Digembalakan di Berbagai Variasi Lamanya Penggembalaan

\begin{tabular}{|c|c|c|c|c|c|}
\hline \multirow{2}{*}{$\begin{array}{c}\text { Lama } \\
\begin{array}{c}\text { Penggembalaan } \\
\text { (jam) }\end{array} \\
<4\end{array}$} & \multicolumn{2}{|c|}{$\begin{array}{l}\text { Induk Melahirkan } \\
\text { Ekor (\%) }\end{array}$} & \multicolumn{2}{|c|}{$\begin{array}{c}\text { Induk Bunting Kembali } \\
\text { Ekor (\%) }\end{array}$} & \multirow{2}{*}{$\begin{array}{c}\text { Total Populasi } \\
\text { (Ekor) }\end{array}$} \\
\hline & 16 & $(84,21)$ & 4 & 21,05 & \\
\hline $4-6$ & 15 & $(71,43)$ & 4 & 19,05 & (21) \\
\hline$>6$ & 11 & $(50,00)$ & 7 & 31,82 & (22) \\
\hline
\end{tabular}

Berdasarkan data pada Tabel 2 terungkap bahwa lamanya penggembalaan tidak mengganggu proses reproduksi domba betina dewasa. Domba induk cukup produktif dan sanggup melahirkan anak yang dikandungnya, serta dapat bunting kembali sekali pun memperoleh pakan dengan digembalakan $<4$ jam.

Selama penelitian berlangsung, induk domba yang digembalakan $<4$ jam memiliki jumlah induk melahirkan paling banyak yaitu 16 ekor dari 19 ekor (84,21\%). Hal tersebut diduga karena pejantan berada di dalam kandang bersama-sama dengan domba betina, sehingga pejantan lebih mudah mengawini domba betina saat estrus. Selain itu rasio antara pejantan dengan betina lebih sedikit (1: 19) dibadingkan penggembalaan $>4$ jam. Rasio ideal pejantan dengan betina dewasa yang dikawinkan secara alami adalah 1 : 5-10 ekor (Permentan RI No. 57, 2006).

\section{Tipe Kelahiran}

Tipe kelahiran adalah Gambaran jumlah anak yang dilahirkan dari seekor induk. Terdapat dua tipe kelahiran yaitu tipe kelahiran tunggal dan tipe kelahiran kembar. Anak yang dilahirkan hanya berjumlah satu ekor disebut kelahiran tunggal, dan anak yang dilahirkan lebih satu ekor disebut kelahiran kembar.

Grafik di bawah menunjukkan bahwa semakin lama durasi penggembalaan, maka kecenderungan terhadap tipe kelahiran kembar semakin tinggi. Hal tersebut terjadi jika dikaitkan dengan kuantitas pakan yang dikonsumsi, semakin lama penggembalaan akan semakin banyak pula rumput yang dikonsumsinya. Lebih banyak pakan yang dikonsumsi, maka kebutuhan tubuh sesuai dengan kondisi faalinya akan terpenuhi.
Penelitian Blakely dan Bade (1994) menunjukkan bahwa melalui perbaikan pakan (flushing) pada domba betina dapat meningkatkan terjadinya kelahiran kembar. Selain faktor pakan, jumlah anak yang dilahirkan dipengaruhi pula oleh umur induk, pertambahan bobot badan induk, bangsa induk dan sistem manajemen (Dimsoski dkk, 1999; Inounu dkk., 1999).

\section{Lamb Crop}

Lamb crop atau lebih dikenal dengan rataan jumlah anak sekelahiran (JAS) adalah kemampuan induk dalam menghasilkan anak per kelahiran. Lamb crop pada masing-masing perlakuan mulai dari lama penggembalaan $<4$ jam, $4-6$ jam, dan $>6$ jam dalam penelitian ini adalah 1; 1,10; dan 1,18 ekor. Lamb crop dalam penelitian ini lebih rendah jika dibandingkan hasil penelitian inounu et al. (1999) yaitu 1,77 ekor, begitu juga dengan hasil penelitian Tiesnamurti (2002) yaitu 1,98 ekor dan Gatenby (1991) yang melakukan penelitian terhadap domba tropis dengan lamb cropnya sebanyak 1,36 ekor.

Faktor-faktor yang mempengaruhi lamb crop adalah genotip, manajemen, interaksi antara manajemen dengan paritas induk, dan pertambahan bobot badan induk (Tiesnamurti, 2002). Faktor lain yang menyebabkan lamb crop Domba Lokal betina dewasa yang digembalakan di daerah Irigasi Rentang Kabupaten Majalengka tergolong rendah, diduga karena unsur kesengajaan dari peternak yang menginginkan induk domba yang dipeliharanya memiliki keturunan tunggal. Mereka berpendapat bahwa induk domba yang memiliki tipe kelahiran tunggal, keturunannya akan cepat besar dan resiko kematian anaknya lebih rendah, sehingga secara ekonomis akan lebih menguntungkan. 


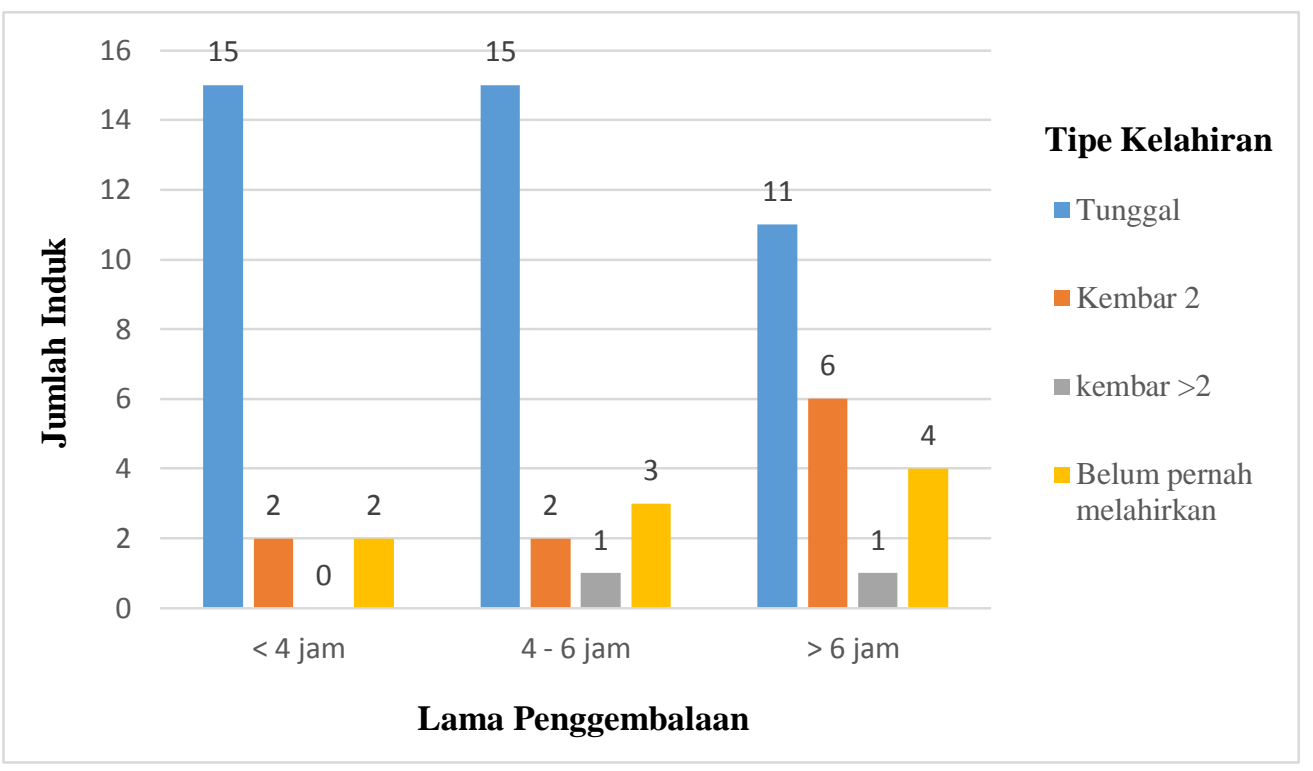

Gambar 1. Grafik Tipe Kelahiran Induk Berdasarkan Lamanya Penggembalaan

Hasil penelitian Kostaman dan Sutama (2006) memperkuat pernyataan para peternak di lokasi penelitian yang menyatakan bahwa lamb crop yang tinggi akan diikuti dengan tingginya tingkat kematian anak yang baru lahir dan dapat menurunkan bobot lahir anak. Pendapat peternak bahwa dengan lamb crop yang kecil atau tipe kelahiran tunggal akan memberikan keuntungan ekonomis lebih besar sebetulnya adalah keliru. Pemikiran mereka hanya melihat berdasarkan banyaknya jumlah kematian anak pada tipe kelahiran kembar atau lamb crop-nya tinggi, sehingga dipandang kurang menguntungkan. Padahal sistem pemeliharaan secara ekstensif dapat menyebabkan kematian domba dengan tipe kelahiran kembar lebih dari satu menjadi cukup tinggi, sepeti dilaporkan hasil penelitian Yulistiani et al. (2003) terahadap peternak di Kabupaten Purwakarta.

\section{Rasio Jenis Kelamin Anak}

Rasio jenis kelamin anak adalah persentanse anak jantan dan betina. Hasil penelitian menunjukkan bahwa secara keseluruhan rasio jenis kelamin anak betina lebih banyak dibandingkan jantan. Jumlah anak domba berjenis kelamin betina sebanyak 58,82\% (40 ekor) dan jantan 41,18\% (28 ekor) dari total anak yang lahir pada saat penelitian sebanyak 68 ekor. Jumlah anak domba berjenis kelamin betina terbanyak yaitu pada lama penggembalaan $4-6$ jam. Banyaknya jenis kelamin betina anak domba yang dilahirkan diduga dapat disebabkan oleh kualitas pakan yang dikonsumsi.

Kualitas hijuan berkaitan dengan kondisi tanah tempat tumbuhnya tanaman tersebut. Jenis tanah di daerah penelitian tergolong ke dalam tanah Alluvial. Notohadiprawiro (2006) menyatakan bahwa tanah Alluvial merupakan tanah yang sangat masam $(\mathrm{pH} 3,5$ atau kurang). Sehingga dapat diduga bahwa keasaman rumputnya pun cukup tinggi. Pakan dengan kandungan asam tinggi dapat mempengaruhi jenis kelamin anak yang dilahirkan.

Fathul dkk. (2008) menyatakan bahwa pakan dengan penambahan anion dapat menurunkan $\mathrm{pH}$ vagina, dan pakan yang ditambahkan Kation dapat meningkatkan $\mathrm{pH}$ vagina. Peningkatan $\mathrm{pH}$ cairan vagina pada saat IB/konsepsi sebesar satu satuan akan meningkatkan rasio kelamin anak sebesar 94,044\%. Sebesar $56 \%$ rasio kelamin anak dipengaruhi oleh $\mathrm{pH}$ cairan vagina pada saat IB atau konsepsi.

Menurut Pratt et al. (1987), pH vagina mempengaruhi rasio kelamin anak, sehingga $\mathrm{pH}$ vagina berhubungan dalam pengaturan rasio seks prefertilisasi. Keasaman cairan vagina mempengaruhi jenis kelamin anak karena adanya perbedaan daya gerak dan ketahanan hidup antara sperma $X$ dan $Y$ untuk mencapai ke sel telur untuk melakukan fertilisasi di ampula tuba falopii. Pratt et al. (1987) dan Budinurdjaja (2007) menyatakan sperma Y tidak tahan pada kondisi asam dibandingkan sperma $X$.

\section{Bobot Lahir}

Secara keseluruhan data pada Tabel 3 menunjukkan bahwa bobot lahir anak betina lebih tinggi dari bobot lahir anak jantan. Hal tersebut bisa disebabkan oleh tipe kelahiran tunggal pada anak betina dan rataan bobot badan induknya. Devendra and McLeroy (1982) menyatakan anak domba tipe kelahiran tunggal mempunyai perkembangan janin pada rahim induk domba yang lebih baik daripada tipe kelahiran kembar 2 dan kembar 3. Adanya pengaruh antara tipe kelahiran terhadap bobot lahir anak domba kemungkinan disebabkan oleh adanya kompetisi dalam uterus untuk mendapatkan zat-zat makanan yang terbatas dari induk melalui plasenta (Hinch et al., 1983). 
I J A S Vol. 7 |Nomor 3 Edisi Desember 2017

Tabel 3. Bobot Lahir Anak Berdasarkan Lamanya Penggembalaan Induk

\begin{tabular}{cccccc}
\hline \multirow{2}{*}{$\begin{array}{c}\text { Lama } \\
\text { Penggembalaan }\end{array}$} & \multicolumn{2}{c}{ Jantan } & \multicolumn{2}{c}{ Betina } & Jumlah Anak \\
\cline { 2 - 6 } & $\mathbf{n}$ (ekor) & BL (kg) & n (ekor) & BL (kg) & N (ekor) \\
\hline <4 Jam & 3 & $2,07 \pm 0,48$ & 4 & $2,05 \pm 0,10^{\text {a }}$ & 7 \\
4-6 Jam & 4 & $1,88 \pm 0,18$ & 3 & $2,00 \pm 0,30^{\text {a }}$ & 7 \\
>6 Jam & 7 & $2,13 \pm 0,36$ & 4 & $2,45 \pm 0,09^{b}$ & 11 \\
\hline Jumlah \& Rataan & $\mathbf{1 4}$ & $\mathbf{2 , 0 3 \pm 0 , 2 2}$ & $\mathbf{1 1}$ & $\mathbf{2 , 1 8 \pm 0 , 1 6}$ & $\mathbf{2 5}$
\end{tabular}

Keterangan : Superskrip huruf yang berbeda pada kolom yang sama menunjukkan perbedaan yang nyata $(P<0,05)$

Tabel 4. Bobot Sapih Anak umur 4 bulan Berdasarkan Lamanya Penggembalaan Induk

\begin{tabular}{cccccc}
\hline \multirow{2}{*}{$\begin{array}{c}\text { Lama } \\
\text { Penggembalaan }\end{array}$} & $\begin{array}{c}\mathbf{n} \\
\text { (ekor) }\end{array}$ & BS (kg) & n (ekor) & BS (kg) & N (ekor) \\
\cline { 2 - 6 } & 7 & $9,40 \pm 0,52$ & 7 & $8,77 \pm 0,38^{\text {a }}$ & 14 \\
44 Jam & 5 & $9,24 \pm 0,38$ & 13 & $8,83 \pm 0,66^{\text {a }}$ & 18 \\
>6 Jam & 11 & $10,11 \pm 1,06$ & 9 & $10,17 \pm 1,16^{\text {b }}$ & 20 \\
\hline Jumlah \& Rataan & $\mathbf{2 3}$ & $\mathbf{9 , 7 0 \pm 0 , 5 4}$ & $\mathbf{2 9}$ & $\mathbf{9 , 2 3 \pm 0 , 5 2}$ & $\mathbf{5 2}$
\end{tabular}

Keterangan : - Superskrip huruf yang berbeda pada kolom yang sama menunjukkan perbedaan yang sangat nyata $(P<0,05)$

BS : Bobot Sapih

Bobot lahir anak betina pada penggembalaan induk $>6$ jam berbeda nyata $(p<0,05)$ lebih berat dibandingkan bobot lahir anak betina pada penggembalaan induk < 6 jam. Faktor konsumsi pakan induk menjadi penentu pula terhadap bobot anak yang dilahirkannya. Bobot lahir jantan pun demikian, walaupun perbedaaannya tidak nyata $(p>0,05)$.

Rendahnya bobot lahir anak domba yang induknya digembalakan di Daerah Irigasi Retang Kabupaten Majalengka diduga disebabkan oleh rendahnya bobot induk. Campbell et al. (2003) menyatakan bahwa bobot induk yang rendah berhubungan dengan manajemen pemberian pakan yang kurang baik, dan Inounu et al. (1999) berpendapat bahwa induk domba dengan bobot

Data hasil penelitian yang terlihat pada Tabel 4 menunjukkan bahwa bobot sapih anak Domba Lokal umur empat bulan yang induknya digembalakan di daerah Irigasi Rentang Kabupaten Majalengka memiliki perbedaan yang tidak nyata, kecuali pada bobot sapih anak betina yang digembalakan $>6$ jam. Bobot sapih anak betina yang digembalakan $>6$ jam memiliki bobot tertinggi yaitu seberat $10,17 \pm 1,16 \mathrm{~kg}$ dan memliki perbedaan yang nyata $(P<0,05)$ lebih berat dibanding dengan bobot sapih anak domba betina lainnya. Hal tersebut diduga karena banyaknya anak domba betina bertipe kelahiran tunggal pada lamanya penggembalaan $>6$ jam. Selain itu, faktor lamanya penggembalaan menjadi pembeda terhadap jumlah pakan yang dikonsumsi.

Semakin lama induknya digembalakan semakin banyak pula pakan yang dikonsumsi, sehingga produksi susunya lebih banyak. Air susu merupakan satu-satunya nutrisi yang sangat penting yang dibutuhkan yang rendah akan melahirkan anak dengan bobot lahir yang rendah juga.

\section{Bobot Sapih}

Bobot sapih adalah bobot disaat anak domba mulai dipisahkan dari induknya. Bobot sapih anak menggambarkan produksi susu dari induk, produksi susu induk yang tinggi dapat menghasilkan bobot sapih anak yang lebih tinggi (Harahap, 2008). Pengukuran bobot sapih dalam penelitian ini adalah pada anak domba yang telah dipisahkan dari induknya atau yang telah berhenti menyusu. Rata-rata anak domba yang telah disapih adalah berumur empat bulan.

pertumbuhan anak domba terutama selama belum mampu makan rumput. Jarmuji (2010) menyatakan bahwa Produksi susu induk sangat nyata $(P<0,01)$ berpengaruh terhadap bobot sapih anak domba ekor tipis Jawa. selama periode lahir sampai sapih umur delapan minggu anak domba masih menggantungkan sumber makanan dari susu induk, meskipun sebagian besar sudah mulai belajar memakan rumput.

\section{Tingkat Mortalitas Anak}

Mortalitas (tingkat kematian) anak adalah persentase kematian anak yang didapat dari jumlah anak yang mati dibagi jumlah anak yang dilahirkan. kematian anak ini memperlihatkan berapa besar daya hidup anak setelah dilahirkan. Persentase kematian anak Domba Lokal yang digembalakan di Daerah Irigasi Rentang Kabupaten Majalengka dapat dilihat pada Gambar 2. 


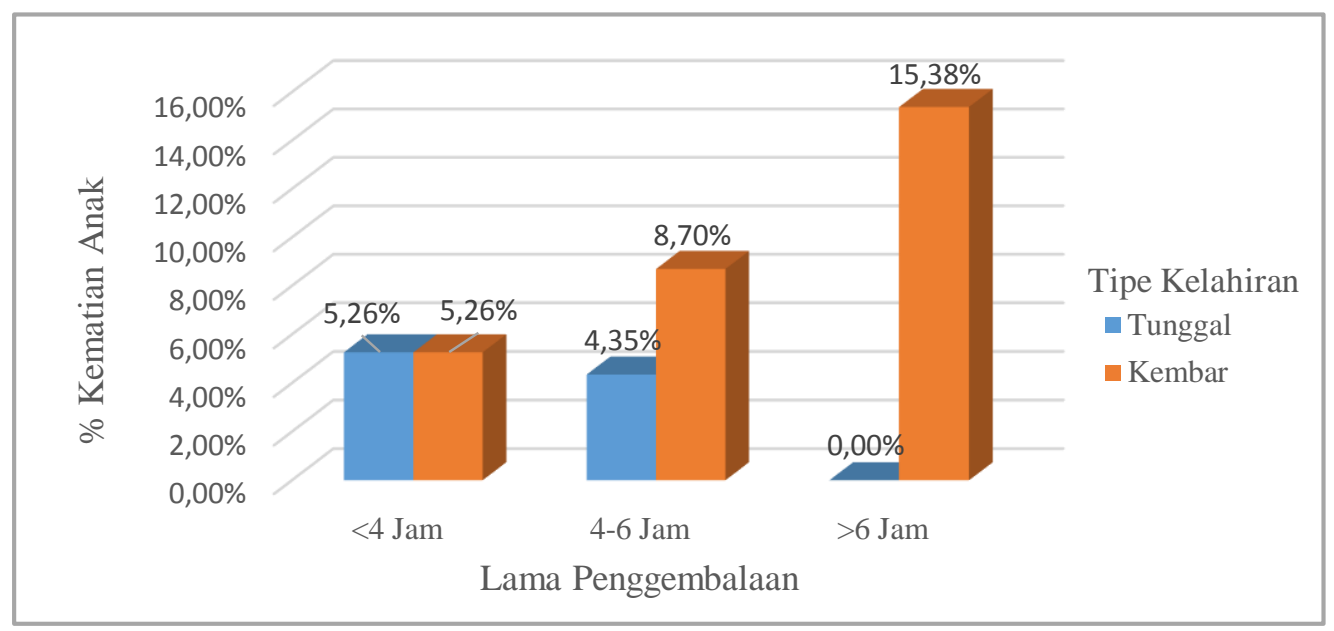

Gambar 2. Grafik Persentase Mortalitas Anak Domba Lokal Berdasarkan Lama Penggembalaan dan Tipe Kelahiran

Grafik pada Gambar 2 menunjukkan bahwa tipe kelahiran sangat berpengaruh terhadap tingkat kematian anak Domba Lokal yang digembalakan, sementara itu tipe kelahiran banyak dipengaruhi oleh lamanya penggembalaan (Gambar 1). Rata-rata jumlah kematian yang tinggi terjadi pada tipe kelahiran kembar. Semua anak domba yang mati pada lama penggembalaan $>6$ jam adalah dengan tipe kelahiran kembar yaitu sebanyak 4 ekor dari 26 ekor anak yang dilahirkan (15,38\%). Grafik di atas juga menunjukkan bahwa kemampuan bertahan hidup anak domba setelah dilahirkan pada tipe kelahiran tunggal lebih tinggi.

Tingkat mortalitas anak keseluruhan pada penelitian ini adalah 13,24\% (9 dari 68 ekor anak yang dilahirkan). Kondisi ini lebih rendah dibandingkan beberapa penelitian lain seperti Inounu (1996) di dalam Harahap (2008) yaitu sebesar 26,07\%, Devendra dan McLeroy (1982) yaitu $20 \%$ tingkat mortalitas anak domba di daerah tropis. Keragaman tingkat mortalitas ini dipengaruhi oleh interaksi genotip dengan manajemen, dan paritas induk (Inounu, 1996 di dalam Harahap, 2008). Sementara faktor lain yang sangat mempengaruhi tingkat mortalitas anak domba setelah dilahirkan adalah tipe kelahiran. Tingkat mortalitas anak kelahiran kembar lebih tinggi dibandingkan anak kematian tunggal (Putu, 1989). Tingkat kematian anak domba ini bisa terjadi karena adanya persaingan untuk mendapatkan air susu induk antara anak domba, dan induk tidak mau menyusui anaknya. Sehingga salah satu dari anak domba kekurangan kebutuhan dari air susu induk (Harahap, 2008)

\section{SIMPULAN}

Berdasarkan hasil dan pembahasan dapat ditarik suatu simpulan bahwa performa Domba Lokal betina dewasa terbaik yang digembalakan di daerah Irigasi Rentang Kabupaten Majalengka adalah pada penggembalaan $>6$ jam. Kondisi tersebut ditunjukkan oleh hasil penelitian sebagai berikut :

1) Rata-rata bobot badan induk yang digembalakan $>6$ jam lebih baik dibandingkan penggembalaan $<4$ jam, namun tidak menunjukan perbedaan yang berarti dengan penggembalaan $4-6$ jam.

2) Kemampuan induk untuk kembali bunting setelah melahirkan, tipe kelahiran kembar, lambcrop, bobot lahir, dan bobot sapih anak yang digembalakan $>6$ jam lebih baik dibanding dengan yang digembalakan < 6 jam,

3) Tidak terjadi kematian anak setelah lahir dengan tipe kelahiran tunggal pada penggembalaan $>6$ jam.

\section{DAFTAR PUSTAKA}

Badan Standardisasi Nasional, 2009. Bibit Domba Garut. Melalui http://blogs.unpad.ac.id/dombagarut/files/2011/09/sni 75322009 bibit domba garut.pdf. [9-9-2014].

Blakely, J. dan D. H. Bade, 1994. Ilmu Peternakan. Edisi keempat. Gadjah Mada University Press, Yogyakarta.

Budinurdjaja, P. 2007. Kiat Mendapatkan Bayi Normal: Menjawab Masalah Seputar Kehamilan. Edisi pertama. Penerbit Pustaka Banua, Banjarmasin Kalimantan Selatan.

Campbell, J. R., M. D. Kenealy, dan K. L. Campbell. 2003. Animal Science. 4th ed. The Biology, care, and production of domestic animals. McGraw-Hill Companies, Inc. New York.

Departemen Pekerjaan Umum, 2008. Laporan Executive Summary: Studi Penyusunan Rehabilitasi Sistem Jaringan Irigasi Rentang di Kabupaten Indramayu, Cirebon dan Majalengka. Jasakon Putra Utama. Bandung. 
I J A S Vol. 7 |Nomor 3 Edisi Desember 2017

Devendra, C. dan G. B. McLeroy. 1982. Goat and Sheep Production in the Tropics. $1^{\text {st }}$ Ed. Oxpord University Press, Oxford.

Dimsoski, P., J. Tosh, J. C. Clay dan K. M. Irvin. 1999. Influence of management system on litter size, lamb growth, and carcass characteristics in sheep. J. Anim. Sci. 77: 1037-1043.

Fathul F., T. Toharmat, I. G. Permana, dan A. Boediono, 2008. Keasaman Cairan Tubuh dan Rasio Kelamin Anak Domba Garut (Ovis aries) yang Diberi Kation-Anion Ransum yang Berbeda. Jurnal Media Peternakan. Vol. 31 No. 2.

Gasperz, V. 1995. Teknik Analisis dalam Penelitian Percobaan. Tarsito, Bandung.

Gatenby, R. M. 1991. Sheep. The Tropical Agriculturalist. Mac Millan Education Ltd. London and Basingtoke.

Harahap, A. S., 2008. Pengaruh Umur Terhadap Performa Reproduksi Induk Domba Lokal yang Digembalakan di UP3 Jonggol. Fakultas Peternakan IPB. Bogor.

Hinch, G. N., R. W. Kelly, J. I. Owens dan S.F. Croble. 1983. Pattern of Lamb Survival High Fecundity Boorola Flocks. Proc. Of The N. Z. Soc. Animal. Prod. 43 : 29-32.

Inounu, I. B., B. Tiesnamurti, Subandriyo dan H. Martojo. 1999. Produksi anak pada domba prolifik. Jurnal Ilmu Ternak 4(3): 25-38.

Jarmuji, 2010. Produksi Susu Induk Terhadap Pengaruh Pertambahan Bobot Badan, Bobot Sapih Dan Daya Hidup Anak Domba Ekor Tipis Jawa Periode Prasapih. Jurnal Sain Peternakan Indonesia Vol. 5, No. 1.

Kostaman, T dan I. K Sutama,. 2006. Korelasi bobot badan induk dengan lama bunting, litter size, dan bobot lahir anak Kambing Pera-nakan Etawah. Seminar Nasional Teknologi Peternakan dan Veteriner: 522-527

Notohadiprawiro, T. 2006. Persoalan Tanah Masam dalam Pembangunan Pertanian di Indonesia. Melalui http://soil.blog.ugm.
ac.id/files/2006/11/1980-Persoalan-

tanah.pdf. [18-9-2015].

Peraturan Menteri Pertanian No. 57 (2006). Pedoman Pembibitan Kambing dan Domba yang Baik (Good Breeding Practice). Melalui http://perundangan.pertanian.go.id/admin/fil e/Permentan-57-06.pdf. Halaman 12.

Pratt, N.C., U.W. Huck \& R.D. Lisk. 1987. Offspring sex ratio in hamsters is correlated with vaginal $\mathrm{pH}$ at certain times of mating. Behav. Neural. Biol. 48:310-316.

Putu, I. G. 1989. Tingkat makanan yang rendah pada akhir masa kebuntingan mempengaruhi sifat keindukan dan menaikkan angka kematian anak domba kelahiran kembar. Balai Penelitian Ternak, Bogor.

Steel R. G. D. dan J. H. Torrie. 1993. Prinsip dan Prosedur Statistika. Suatu Pendekatan Biometrik. PT. Gramedia Pustaka Utama. Jakarta.

Syuhada I, D. Heriyadi, dan A. Sarwestri, 2014. Identifikasi Bobot Badan Dan Ukuran-Ukuran Tubuh Domba Wonosobo Betina Pada Kelompok Peternak Di Kecamatan Kejajar Kabupaten Wonosobo. Melalui http://download.portalgaruda.org/article.php . [17-9-2015].

Tiesnamurti, B. 2002. Kajian genetik terhadap induk domba Priangan peridi ditinjau dari aspek kuantitatif dan molukuler. Disertasi. Program Pascasarjana, Institut Pertanian Bogor, Bogor.

Yulistiani, D., M. martawijaya, isbandi, B. setiadi dan subandriyo. 2003. Tata laksana pemberian pakan dan tingkat kematian anak pra sapih pada domba di Desa Pasiripis Kabupaten Majalengka dan Desa Tegalsari Kabupaten Purwakarta. Pros. Seminar Nasional Teknologi Peternakan dan Veteriner. 2003. Bogor, 29-30 September 2003. Pusat Penelitian dan Pengembangan Peternakan. Bogor. HI,. 114119. 